\title{
Renal involvement in active 'juvenile' cirrhosis
}

\author{
HOMERO SILVA, ELIZABETH W. HALL, KENNETH R. HILL, \\ STANLEY SHALDON, AND SHEILA SHERLOCK
}

From the Departments of Medicine and Pathology, Royal Free Hospital, London

SYNOPSIS Twelve patients with active 'juvenile' cirrhosis (active chronic hepatitis, 'lupoid' hepatitis) and six subjects with other types of portal or postnecrotic cirrhosis were submitted to percutaneous renal biopsy. In addition, renal function was assessed in all patients by measurement of the 24-hour endogenous creatinine clearance, maximal urinary osmolality after deprivation of water, 24-hour urinary protein excretion, and routine urine analysis.

Renal function was not significantly abnormal in either group of patients, but seven of the 12 patients with active 'juvenile' cirrhosis showed mild histological changes on renal biopsy. These changes are very similar to the lesions described in early 'lupus nephritis'.

The significance of these findings in relation to the aetiology of active 'juvenile' cirrhosis is discussed.

In recent years a newly recognized syndrome affecting the liver has attracted increasing attention. Since the first description of the syndrome (Waldenström, 1950), a number of cases have been reported (Kunkel, Ahrens, Eisenmenger, Bongiovanni, and Slater, 1951; Joske and King, 1955; Bettley, 1955; Mackay, Taft, and Cowling, 1956; Bearn, Kunkel, and Slater, 1956; Heller, Zimmerman, Rozengvaig, and Singer, 1956; Bartholomew, Hagedorn, Cain, and Baggenstoss, 1958; Mackay et al., 1959; Aronson and Montgomery, 1959; Page and Good, 1960; Bartholomew et al., 1960; Willocx and Isselbacher, 1961; Jones and Castleman, 1962; Mackay and Wood, 1962; Read, Sherlock, and Harrison, 1963). The disease has been given various names by different authors. The most common designations include 'active chronic viral hepatitis' (Joske and King, 1955; Bettley, 1955), 'lupoid hepatitis' (Mackay et al., 1956), 'plasma-cell hepatitis' (Page and Good, 1960), and 'active "juvenile" cirrhosis" (Read et al., 1963). The last will be used throughout this communication.

The term active "juvenile' cirrhosis describes a group of patients showing all or most of the following features: marked hypergammaglobulinaemia, raised serum transaminase and serum bilirubin levels, and cirrhosis, usually postnecrotic in character (Read et al., 1963). A prominent feature of the liver histology is the plasma cell and lymphocytic infiltration and the tendency for the liver cells to take up a rosette-like formation.

Received for publication 4 June 1964.
The aetiology of the disease remains unknown. Some authors (Joske and King, 1955; Bettley, 1955) favour a viral origin. Alternatively, this entity has been regarded as an unusual manifestation of systemic lupus erythematosus, as some of the patients have had positive L.E. cell tests and related systemic manifestations (Bartholomew et al., 1958 and 1960).

Since the kidneys are the organs most frequently affected in systemic lupus erythematosus, it was decided to investigate patients with active juvenile cirrhosis for evidence of renal involvement, and perhaps obtain further evidence of involvement of more than one system in this disease.

\section{MATERIAL AND METHODS}

Twelve patients with active juvenile cirrhosis (four males and eight females), age range 14-66 years (mean 27 years), and six patients (five males and one female), age range 37-60 years (mean 50 years) with a cirrhosis not typical of the juvenile group were studied and the clinical and laboratory findings are summarized in Table I. The separation of these patients into the two groups was based primarily on the appearances of the liver biopsy. The 'non-juvenile' group included three alcoholic patients (cases 14, 16, and 17) with a fine portal cirrhosis and three non-alcoholic patients (cases 13, 15, and 18) with postnecrotic cirrhosis. The non-juvenile group will be referred to as portal cirrhosis in distinction to the group with juvenile cirrhosis. In the juvenile group, the duration of illness from the onset of the first significant symptom of liver disease to the time of study ranged from five to 54 months. Associated systemic manifestations included Raynaud's phenomenon (case 1), thyroiditis with hyper- 
TABLE I

CLINICAL AND LABORATORY DATA ON 18 PATIENTS WITH CIRRHOSIS OF THE LIVER

$\begin{array}{lllllllll}\text { Case } & \text { Age } & \text { Duration } & \text { Serum } & \text { S.G.O.T. } \\ \text { No. } & \text { Sex } & \begin{array}{l}\text { of Disease } \\ \text { (mth.) }\end{array} & \begin{array}{l}\text { Bilirubin } \\ \text { (mg./100 ml.) }\end{array} & \begin{array}{l}\text { Hyper- } \\ \text { gamma- } \\ \text { globulin- }\end{array} & \text { L.E. Cells } & \begin{array}{l}\text { Anti- } \\ \text { nuclear }\end{array} & \begin{array}{l}\text { Cortico- } \\ \text { steroid }\end{array} & \text { Associated Conditions } \\ & & & & & \text { Factor } & \text { Therapy }\end{array}$

\begin{tabular}{|c|c|c|c|c|c|c|c|c|}
\hline \multicolumn{9}{|c|}{ Active juvenile cirrhosis } \\
\hline 1 & 30, $\mathrm{F}$ & $2 \cdot 6$ & 425 & $+t+$ & $\mathbf{0}$ & $\mathbf{0}$ & + & Raynaud's phenomenon \\
\hline 2 & $21, F$ & 1.6 & 440 & $+t+$ & 0 & $1: 5$ & 0 & Hyperthyroidism \\
\hline 3 & $14, \mathrm{M}$ & $2 \cdot 7$ & 300 & $+t+$ & + & $1: 100$ & + & Hypokalaemic nephropathy \\
\hline 4 & $15, \mathrm{M}$ & 0.5 & 36 & $+t$ & $\mathbf{0}$ & $\mathbf{0}$ & + & Ulcerative colitis \\
\hline 5 & $16, M$ & $3 \cdot 1$ & 42 & + & $\mathbf{0}$ & $\mathbf{0}$ & $\mathbf{0}$ & None \\
\hline 6 & $25, \mathrm{~F}$ & $11 \cdot 0$ & 355 & $+t+$ & + & $1: 20$ & 0 & Ulcerative colitis \\
\hline 7 & $17, \mathbf{M}$ & 0.9 & 32 & $+t$ & 0 & $1: 5$ & + & Cerebrovascular disease \\
\hline 8 & $66, F$ & 3.0 & 250 & $++t$ & 0 & $1: 200$ & 0 & None \\
\hline 9 & $18, F$ & $1 \cdot 2$ & 70 & $++t$ & 0 & $1: 10$ & + & Ulcerative colitis \\
\hline 10 & $58, F$ & $0 . \overline{7}$ & 70 & ++ & 0 & 0 & + & Chronic pyelonephritis \\
\hline 11 & $32, \mathbf{F}$ & $1 \cdot 0$ & 11 & $+t+$ & $\mathbf{0}$ & $\mathbf{0}$ & + & None \\
\hline 12 & $15, F$ & $26 \cdot 0$ & 335 & $+t+$ & $\mathbf{0}$ & $1: 20$ & + & None \\
\hline \multicolumn{9}{|c|}{ Portal cirrhosis (alcoholic and non-alcoholic) } \\
\hline 13 & $59, F \quad 48$ & $2 \cdot 4$ & 36 & 0 & 0 & 0 & 0 & None \\
\hline 14 & $49, M$ & $3 \cdot 0$ & 95 & + & $\mathbf{0}$ & $\mathbf{0}$ & 0 & None \\
\hline 15 & $60, M$ & $4 \cdot 0$ & 27 & + & $\mathbf{0}$ & $\mathbf{0}$ & 0 & None \\
\hline 16 & 37, M & $6 \cdot 4$ & 44 & ++ & 0 & 0 & 0 & None \\
\hline 17 & $57, \mathrm{M}$ & $2 \cdot 5$ & 55 & + & 0 & 0 & 0 & None \\
\hline 18 & $41, M$ & 0.8 & 30 & 0 & 0 & 0 & 0 & None \\
\hline
\end{tabular}

thyroidism (case 2), ulcerative colitis (cases 4, 6, and 9), and hemiplegia attributed to cerebral vasculitis (case 7). Eight of the 12 patients had had or were still receiving corticosteroid therapy at the time of study (prednisone or prednisolone, $15-30 \mathrm{mg}$. per day). Serum bilirubin levels were raised in eight patients $(1 \cdot 2-26.0 \mathrm{mg} . / 100 \mathrm{ml}$.$) and$ normal $(<1.0 \mathrm{mg} . / 100 \mathrm{ml}$.) in four. Serum glutamic oxaloacetic transaminase (S.G.O.T.) was raised in 10 patients (36-440 units/l.) and normal in two. Hypergammaglobulinaemia was a conspicuous abnormality in all patients. Three patients (cases 3,6 , and 8 ) had positive L.E. cell tests and/or significant titres of antinuclear factors.

In the 'portal' group, the duration of illness from the onset of the first symptom to the time of study ranged from three to 71 months. There were no associated systemic manifestations present, and none of the patients had received corticosteroid therapy. The serum bilirubin level was raised in five patients (range $2.4-6.4 \mathrm{mg} . / 100 \mathrm{ml}$.) and normal in one patient. The serum glutamic oxaloacetic transaminase (S.G.O.T.) was raised in four patients (range 36-95 units/l.) and normal in two patients. Hypergammaglobulinaemia was present in four patients but less marked than in the juvenile group. Positive L.E. cell tests or significant titres of antinuclear factors were not found in any of these patients.

Renal function was assessed by the following: measuring the 24-hour endogenous creatinine clearance; maximal urinary osmolality, measured with a Fiske osmometer after deprivation of fluid for 24 hours; 24-hour urine protein excretion; routine urine analysis, including microscopic examination of the urinary sediment and culture of a freshly voided clean specimen, and intravenous pyelography. A renal biopsy was then performed using the percutaneous technique (Kark and Muehrcke, 1954). The renal tissue obtained was fixed immediately in $10 \%$ formol saline. After fixation, the specimen was embedded in paraffin wax and serial sections were cut at a thickness of $5 \mu$. All the sections were stained with haematoxylin and eosin, with the periodic-acid-Schiff reagent, and with martius-scarlet-blue stain for fibrinoid (Lendrum, Fraser, Slidders, and Henderson, 1962). A minimum of five sections stained with haematoxylin and eosin and one each with P.A.S. and M.S.B. were studied in each case under the light microscope. Only those sections containing five or more glomeruli and their adjacent tubules were included. In fact, in nine of the 12 patients with active juvenile cirrhosis and in five of the six with portal cirrhosis, the renal biopsies contained more than 10 glomeruli.

\section{RESULTS}

RENAL FUNCTION TESTS These results are summarized in Table II. Both groups of patients had either normal renal function or it was only very slightly impaired. Urine analysis, apart from excess urobilinogen and the presence of bilirubin, was normal in 11 of the 12 patients with active juvenile cirrhosis. Case 1 had an abnormal urine analysis with numerous pus cells due to an Escherichia coli urinary infection. Twenty-four-hour urinary protein excretion ranged from less than 0.1 to $0.4 \mathrm{~g}$. Maximal urinary osmolality ranged from 720 to $1,338 \mathrm{mOsm}$./ kg. in 11 patients, and was severely impaired in case 3 (233 mOsm./kg.), who had an associated hypokalaemic nephropathy. Endogenous creatinine clearance ranged from 60 to $127 \mathrm{ml} . / \mathrm{min} . / 1.73 \mathrm{~m}^{2}$. in 10 patients. It was $44 \mathrm{ml} . / \mathrm{min} . / 17 \cdot 3 \mathrm{~m}^{2}$. in case 3 and $48 \mathrm{ml} . / \mathrm{min} . / 1.73 \mathrm{~m}^{2}$. in case 10 with chronic pyelonephritis. Intravenous pyelography was normal 
TABLE II

RENAL FUNCTION TESTS ON 18 PATIENTS WITH CIRRHOSIS OF THE LIVER

\begin{tabular}{|c|c|c|c|c|c|}
\hline $\begin{array}{l}\text { Case } \\
\text { No. }\end{array}$ & Urine Analysis & Proteinuria $(\mathrm{g} . / 24 \mathrm{hr})$. & $\begin{array}{l}\text { Maximal Urinary } \\
\text { Osmolality (mOsm./kg.) }\end{array}$ & $\begin{array}{l}\text { Endogenous } \\
\text { Creatinine Clearance } \\
\left.\text { (ml./min. } / 1.73 \mathrm{~m}^{2}\right)\end{array}$ & Intravenous Pyelogram \\
\hline \multicolumn{6}{|c|}{ Active juvenile cirrhosis } \\
\hline $\begin{array}{l}1 \\
2 \\
3\end{array}$ & $\begin{array}{l}\text { Urobilinogen } \uparrow \\
\text { Normal } \\
\text { Normal }\end{array}$ & $\begin{array}{r}<0.1 \\
0.4 \\
<0.1\end{array}$ & $\begin{array}{l}964 \\
780 \\
233\end{array}$ & $\begin{array}{r}120 \\
112 \\
44\end{array}$ & $\begin{array}{l}\text { Normal } \\
\text { Normal } \\
\text { Poor excretion on both } \\
\text { kidneys }\end{array}$ \\
\hline $\begin{array}{l}4 \\
5 \\
6\end{array}$ & $\begin{array}{l}\text { Normal } \\
\text { Urobilinogen } \uparrow \\
\text { Urobilinogen } \uparrow\end{array}$ & $\begin{array}{r}<0.1 \\
<0.1 \\
0.4\end{array}$ & $\begin{array}{l}937 \\
955 \\
761\end{array}$ & $\begin{array}{r}127 \\
72 \\
70\end{array}$ & $\begin{array}{l}\text { Normal } \\
\text { Normal } \\
\text { Normal }\end{array}$ \\
\hline & Bilirubin & & & & \\
\hline 7 & Urobilinogen $\uparrow$ & $<0.1$ & 1,338 & 121 & Normal \\
\hline 8 & Urobilinogen $\uparrow$ & 0.2 & 796 & 60 & Normal \\
\hline 9 & Normal & $<0.1$ & 1,328 & 110 & Normal \\
\hline 10 & Pyuria $E$. coli & $<0.1$ & 702 & 48 & Poor excretion on left kidney \\
\hline 11 & Normal & 0.2 & 975 & 115 & Normal \\
\hline 12 & $\begin{array}{l}\text { Urobilinogen } \uparrow \\
\text { Bilirubin }\end{array}$ & $0 . \overline{3}$ & 808 & 92 & Normal \\
\hline \multicolumn{6}{|c|}{ Portal cirrhosis (alcoholic and non-alcoholic) } \\
\hline 13 & Normal & $<0.1$ & 633 & 50 & Normal \\
\hline 14 & Normal & $<0.1$ & 840 & 82 & Normal \\
\hline 15 & Normal & $<0 \cdot 1$ & 800 & 60 & Normal \\
\hline 16 & $\begin{array}{l}\text { Urobilinogen } \uparrow \\
\text { Bilirubin }\end{array}$ & 0.4 & 980 & 100 & Normal \\
\hline 17 & Normal & $<0.1$ & 753 & 112 & Normal \\
\hline 18 & Normal & 0.2 & 1,300 & 80 & Normal \\
\hline
\end{tabular}

TABLE III

RENAL BIOPSY FINDINGS ON 18 PATIENTS WITH CIRRHOSIS OF THE LIVER

\begin{tabular}{|c|c|c|c|c|c|c|c|c|c|c|c|c|}
\hline \multirow[t]{2}{*}{$\begin{array}{l}\text { Case } \\
\text { No. }\end{array}$} & \multicolumn{4}{|c|}{ Glomerular Changes } & \multicolumn{3}{|c|}{ Tubular Changes } & \multicolumn{2}{|c|}{$\begin{array}{c}\text { Interstitial } \\
\text { Changes }\end{array}$} & \multicolumn{2}{|c|}{$\begin{array}{l}\text { Vascular } \\
\text { Changes }\end{array}$} & \multirow[t]{2}{*}{ Pathological Diagnosis } \\
\hline & $\begin{array}{l}\text { Base- } \\
\text { ment } \\
\text { Mem- } \\
\text { brane }\end{array}$ & $\begin{array}{l}\text { Cellu- } \\
\text { larity }\end{array}$ & $\begin{array}{l}\text { Fibri- } \\
\text { noid }\end{array}$ & $\begin{array}{l}\text { 'Wire- } \\
\text { loop' } \\
\text { Lesions }\end{array}$ & $\begin{array}{l}\text { Degene- } \\
\text { ration }\end{array}$ & $\begin{array}{l}\text { Dila- } \\
\text { tation }\end{array}$ & Casts & Fibrosis & $\begin{array}{l}\text { Inflam- } \\
\text { mation }\end{array}$ & $\begin{array}{l}\text { Scle- } \\
\text { rosis }\end{array}$ & $\begin{array}{l}\text { Fibri- } \\
\text { noid }\end{array}$ & \\
\hline
\end{tabular}

\begin{tabular}{|c|c|c|c|c|c|c|c|c|c|c|c|}
\hline \multicolumn{12}{|c|}{ Active juvenile cirrhosis } \\
\hline 1 & + & + & o & 0 & 0 & 0 & 0 & 0 & o & 0 & 0 \\
\hline 2 & + & 0 & 0 & + & + & $\mathbf{0}$ & 0 & 0 & $\mathbf{0}$ & 0 & 0 \\
\hline 3 & + & $\mathbf{0}$ & $\mathbf{0}$ & $\mathbf{0}$ & ++ & ++ & + & ++ & +++ & + & $\mathbf{0}$ \\
\hline 4 & + & 0 & 0 & + & + & + & + & 0 & 0 & 0 & 0 \\
\hline 5 & + & + & 0 & + & 0 & 0 & 0 & 0 & 0 & 0 & 0 \\
\hline 6 & ++ & + & + & + & + & 0 & + & 0 & 0 & 0 & 0 \\
\hline 7 & 0 & 0 & 0 & 0 & 0 & 0 & 0 & 0 & 0 & 0 & \\
\hline 8 & ++ & 0 & 0 & 0 & 0 & 0 & 0 & ++ & 0 & + & \\
\hline 9 & + & 0 & + & 0 & 0 & 0 & 0 & 0 & 0 & 0 & 0 \\
\hline 10 & + & 0 & 0 & 0 & 0 & + & 0 & ++ & ++ & + & \\
\hline 11 & 0 & 0 & 0 & 0 & 0 & 0 & 0 & 0 & 0 & 0 & \\
\hline 12 & ++ & + & 0 & 0 & ++ & 0 & 0 & 0 & 0 & 0 & \\
\hline
\end{tabular}

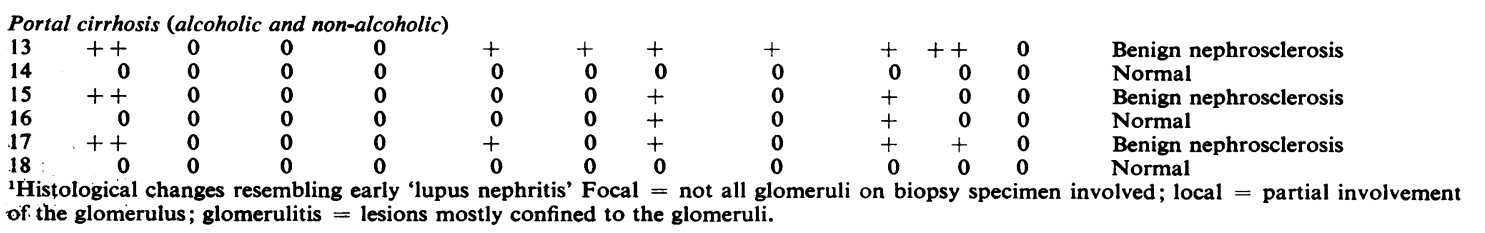

Mild focal and local membranous glomerulitis ${ }^{1}$

Mild focal and local membranous glomerulitis ${ }^{1}$

Hypokalaemic nephropathy

Mild focal and local membranous glomerulitis ${ }^{1}$

Mild focal and local membranous and proliferative glomerulitis ${ }^{2}$ Moderate focal and local membranous glomerulitis ${ }^{1}$ Normal

Benign nephrosclerosis

Mild focal and local membranous glomerulitis ${ }^{1}$

Chronic pyelonephritis

Normal

Moderate focal and local

membranous and proliferative

glomerulitis ${ }^{\mathbf{1}}$ 


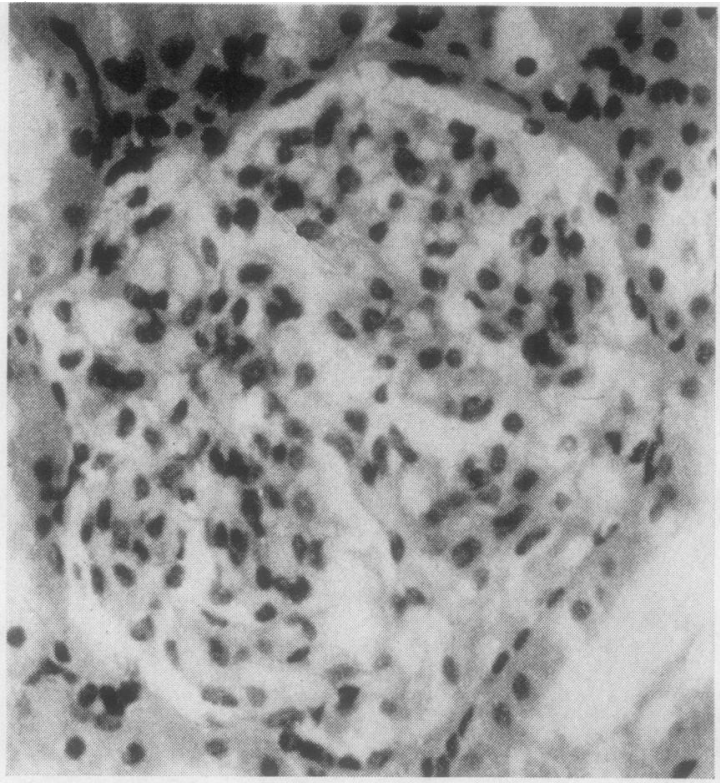

FIG. 1. Case 5. Renal biopsy specimen. There is mild irregular basement membrane thickening, and slight but definite local hypercellularity of the glomerular tuft. (Haematoxylin and eosin, $\times 250$.)

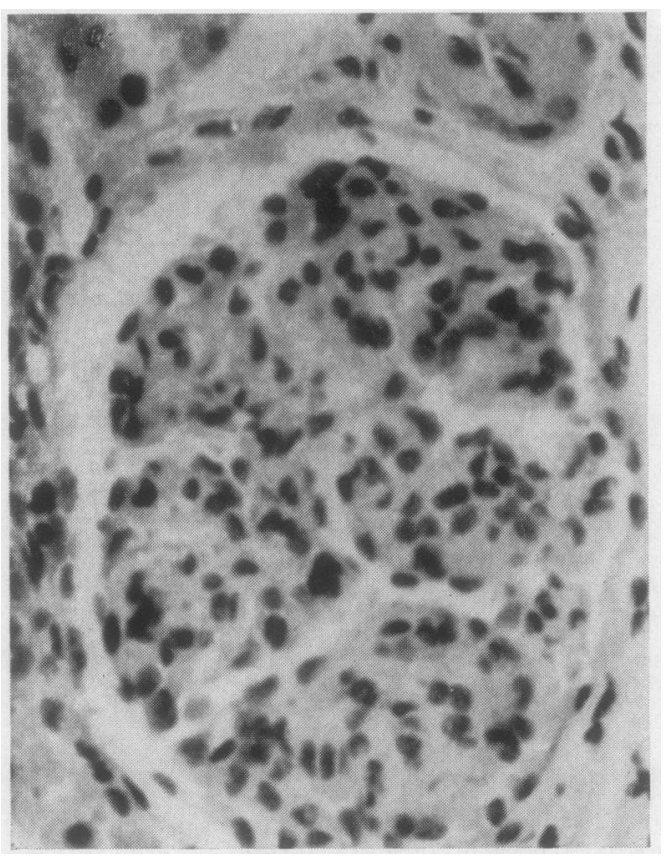

FIG. 2. Case 12. Renal biopsy specimen. The glomerulus is slightly lobulated. A fairly diffuse but irregular thickening of the glomerular basement membrane and a definite hypercellularity in the areas of thickening are present. (Haematoxylin and eosin, $\times 250$.)

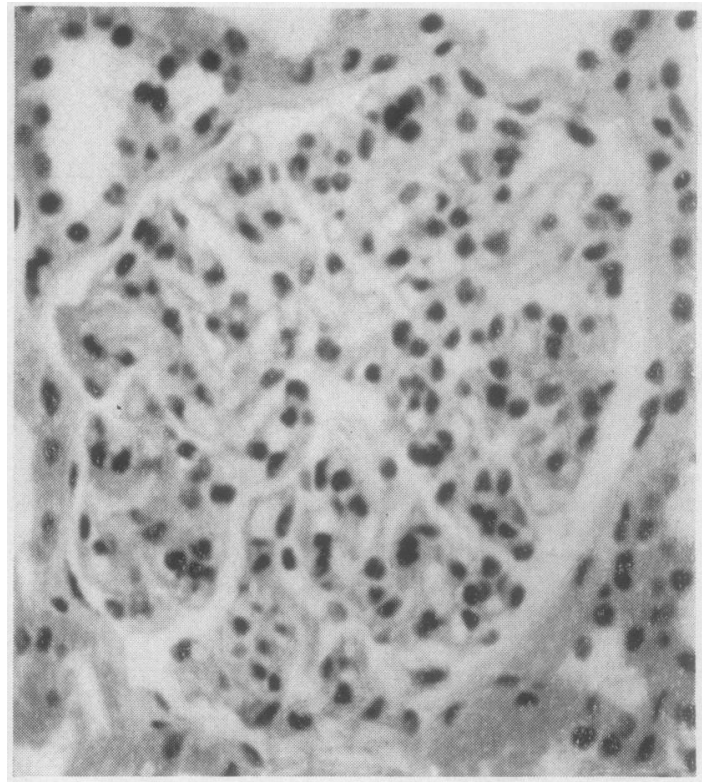

FIG. 3. Case 2. Renal biopsy specimen. There is mild local basement membrane thickening and slight local hypercellularity. Distinct 'wire loops' are present, especially at the periphery of the glomerular tuft. (Haematoxylin and eosin, $\times 250$.)

in 10 patients, and abnormal in the two patients (cases 3 and 10) with associated disease of the kidneys. Urine analysis was normal in all the patients with 'portal' cirrhosis, apart from excess urobilinogen and the presence of bilirubin. Twentyfour-hour urinary protein excretion ranged from less than $0 \cdot 1 \mathrm{~g}$. to $0.4 \mathrm{~g}$. Maximal urinary osmolality ranged from 633 to $1,300 \mathrm{mOsm}$. $/ \mathrm{kg}$. Endogenous creatinine clearance ranged from 50 to $112 \mathrm{ml}$./min./ $1.73 \mathrm{~m}^{2}$. Intravenous pyelography was normal in all patients with portal cirrhosis.

RENAL histological CHANGes Findings were evaluated using the criteria and nomenclature of Muehrcke, Kark, Pirani, and Pollak (1957) and are set out in Table III. As the lesions found in the affected kidneys were of an early nature, histological analysis was confined to the following structural changes: in the glomerulus, thickening of the basement membrane, increased cellularity of the tuft, fibrinoid changes in the capillary walls, and 'wire-loop' lesions; in the tubules, degeneration, dilatation, and the presence of casts in the tubular lumina; in the interstitial tissue, the presence of fibrosis and infiltration with inflammatory cells, and in the vessels, sclerosis and fibrinoid degeneration of their walls. In each case, the severity of the lesions 


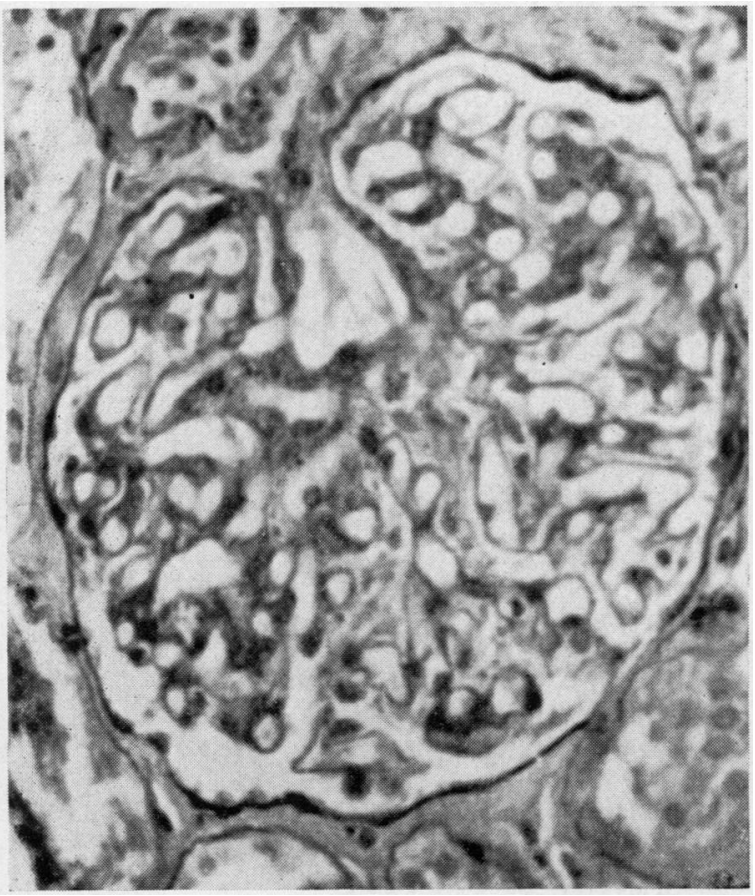

FIG. 4. Case 4. Renal biopsy specimen. Irregular smudgy thickening of the glomerular basement membrane and 'wire loops' throughout the glomerulus are present. (Periodic-acid-Schiff reagent, $\times 250$.)

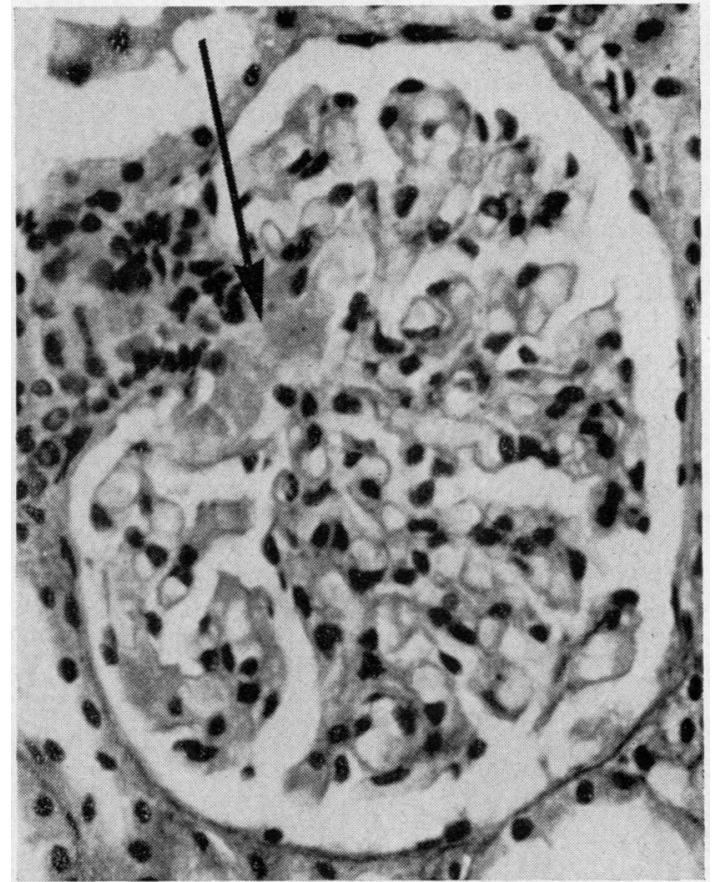

FIG. 6. Case 6. Renal biopsy specimen. There is irregular smudgy thickening of the glomerular basement membrane. Fibrinoid changes in the smudgy areas (arrow) were demonstrated. (Martius-scarlet-blue stain, $\times 250$.)

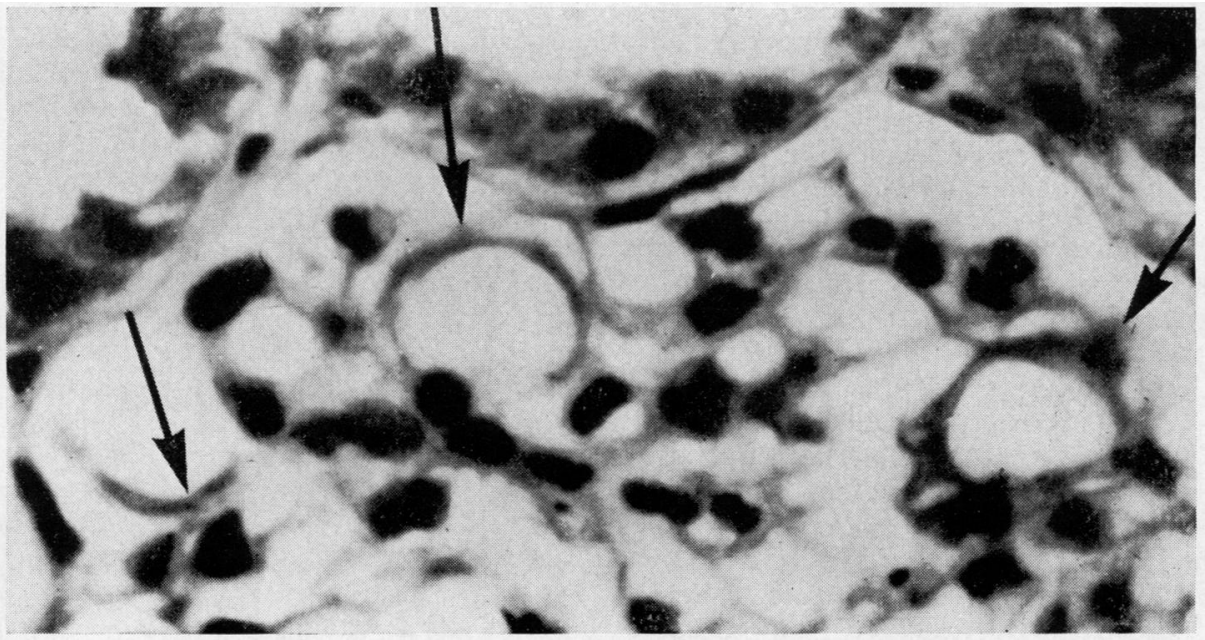

FIG. 5. Case 9. Renal biopsy specimen. Photomicrograph of a portion of a glomerulus. Some of the capillary loops at the periphery of the glomerular tuft have a stiff and slightly smudgy appearance. Fibrinoid degeneration of the basement membrane in some of the involved loops (arrows) was demonstrated. (Martius-scarlet-blue stain, $\times 1,200$.) 
was graded from 0 (normal) to $3+$ (moderately severe changes).

In the group of patients with active juvenile cirrhosis, renal biopsy was normal in two (cases 7 and 11) and abnormal in the remaining 10 . In seven of the 10 patients with abnormal renal biopsies, the changes were mild and were confined to the glomeruli there being no significant involvement of the tubules, interstitial tissue, or vessels. The most prominent histological feature of this 'glomerulitis' was an irregular, patchy thickening of the glomerular basement membrane, with mild local proliferative changes of the glomerular tuft (Figs. 1, 2, and 3), resembling the lesions described in early 'lupus nephritis' (Muehrcke et al., 1957). In addition, four of these patients (cases 2, 4, 5, and 6) had typical 'wire-loop' lesions (Figs. 3 and 4 ) and a further two (cases 6 and 9) showed evidence of mild fibrinoid changes in the glomerular basement membrane (Figs. 5 and 6).

In the other three patients with abnormal renal biopsies, the lesions were consistent with hypokalaemic nephropathy (case 3), benign nephrosclerosis (case 7), and chronic pyelonephritis (case 10).

Among the patients with portal cirrhosis, three (cases 14, 16, and 18) had a normal renal biopsy and the other three (cases 13.15, and 17) showed histological changes consistent with benign nephrosclerosis, most probably related to their age. There was no evidence of histological changes suggestive of lupus nephritis in any of these patients.

\section{DISCUSSION}

The finding of renal histological lesions resembling those of early lupus nephritis in seven out of 12 patients $(58 \%)$ with active juvenile cirrhosis would suggest that the liver is only the predominant target of a type of disease affecting more than one system. Previous reports indicating the association of a nephropathy with active juvenile cirrhosis have dealt either with necropsy material (Bartholomew et al., 1960) or with cases with overt manifestations of renal involvement (Mackay et al., 1956; Bartholomew et al., 1958; Read et al., 1963). However, the finding of renal histological abnormalities in the absence of clinical manifestations or functional impairment suggests that renal involvement in active juvenile cirrhosis may be much commoner than has been previously reported. This observation contradicts the suggestion that lupoid hepatitis (active juvenile cirrhosis) differs from classical systemic lupus erythematosus in the rarity of renal involvement (Mackay and Wood, 1962).

The question arises as to the significance of these renal histological changes, as with the exception of 'haematoxylin' bodies, no other single histological feature can be considered pathognomonic of lupus nephritis (Klemperer, Gueft, Lee, Leuchtenberger, and Pollister, 1950). However, the occurrence in combination of less specific features, i.e., irregular thickening of the glomerular basement membrane, 'wire-loop' lesions, and 'fibrinoid' degeneration, make these lesions indistinguishable from early lupus nephritis seen in patients with classical systemic lupus erythematosus (Muehrcke et al., 1957). The finding of L.E. cells and/or significant titres of antinuclear factors in three of the seven patients with 'glomerulitis' would support this suggestion. However, overt liver involvement in classical systemic lupus erythematosus is rare (Mackay et al., 1959; Jones and Castleman, 1962; Klemperer, Pollack, and Baehr, 1941; Harvey, Shulman, Tumulty, Conley, and Schoenrich, 1954) and would suggest that active juvenile cirrhosis is not merely a hepatic manifestation of systemic lupus erythematosus. Furthermore, glomerular lesions associated with cirrhosis have been described in patients without evidence of involvement of more than one system or positive L.E. cell tests and/or antinuclear factors, but these lesions have been considered non-specific (Baxter and Ashworth, 1946; Patek, Seegal, and Bevans, 1951; Crowson and More, 1955; Bloodworth and Sommers, 1959; Fisher and Hellstrom, 1959).

The absence of a 'glomerulitis' in the 'nonjuvenile' or 'portal' group of patients could be due to chance, as only $58 \%$ of the juvenile group showed these changes. However, it is more likely that the aetiology of cirrhosis differs in the two groups, particularly as there was no evidence that any other system was involved or of positive L.E. cell tests in the group with non-juvenile or portal cirrhosis.

In spite of the structural changes in the glomeruli, renal function in these patients did not appear to be impaired as estimated by standard tests. Moreover, five patients with this syndrome have now been followed for one year and progressive renal damage, as judged by clinical manifestations or evidence of functional impairment, has not ensued. This is in keeping with the fact that overt renal involvement in active juvenile cirrhosis (lupoid hepatitis) has only rarely been observed (Mackay et al., 1956; Read et al., 1963). It seems likely therefore that severe kidney damage would not develop and the presence of glomerular changes does not worsen the already poor prognosis in this group of patients (Read et al., 1963).

The presence of these renal histological lesions must not be an indication for initiating or increasing corticosteroid therapy, which must depend on the assessment of the patient as a whole. 


\section{REFERENCES}

Aronson, A. R., and Montgomery, M. M. (1959). Arch. intern. Med., $104,544$.

Bartholomew, L. G., Cain, J. C., Baggenstoss, A. H., and Hagedorn, A. B. (1960). Gastroenterology, 39, 730.

—, Hagedorn, A. B., Cain, J. C., and Baggenstoss, A. H. (1958). New Engl. J. Med., 259, 947.

Baxter, J. H., and Ashworth, C. T. (1946). Arch. Path., 41, 476.

Bearn, A. G., Kunkel, H. G., and Slater, R. J. (1956). Amer. J. Med., 21, 3.

Bettley, F. R. (1955). Lancet, 2, 724.

Bloodworth, J. M. B. Jr., and Sommers, S. C. (1959). Lab. Invest., 8, 962.

Crowson, C. N., and More, R. H. (1955). Arch. Path., 60, 73.

Fisher, E. R., and Hellstrom, H. R. (1959). Amer. J. clin. Path., 32, 48. Harvey, A. McG., Shulman, L. E., Tumulty, P. A., Conley, C. L., and Schoenrich, E. H. (1954). Medicine (Baltimore), 33, 291.

Heller, P., Zimmerman, H. J., Rozengvaig, S., and Singer, K. (1956). New Engl. J. Med., 254, 1160.

Joske, R. A., and King, W. E. (1955). Lancet, 2, 477.
Jones, W. A., and Castleman, B. (1962). Amer. J. Path., 40, 315.

Kark, R. M., and Muehrcke, R. C. (1954). Lancet, 1, 1047.

Klemperer, P., Gueft, B., Lee, S. L., Leuchtenberger, C., and Pollister, A. W. (1950). Arch. Path., 49, 503.

- Pollack, A. D., and Baehr, G. (1941). Ibid., 32, 569.

Kunkel, H. G., Ahrens, E. H. Jr., Eisenmenger, W. J., Bongiovanni, A. M., and Slater, R. J. (1951). J. clin. Invest., 30, 654.

Lendrum, A. C., Fraser, D. S., Slidders, W., and Henderson, R. (1962). J. clin. Path., 15, 401.

Mackay, I. R., Taft, L. I., and Cowling, D. C. (1956). Lancet, 2, 1323. $\longrightarrow, 1,-$ (1959). Ibid., 1, 65.

- , and Wood, I. J. (1962). Quart. J. Med., (n.s.)., 31, 485.

Muehrcke, R. C., Kark, R. M., Pirani, C. L., and Pollak, V. E. (1957). Medicine (Baltimore), 36, 1.

Page, A. R., and Good, R. A. (1960). Amer. J. Dis. Child., 99, 288.

Patek, A. J. Jr., Seegal, D., and Bevans, M. (1951). Amer. J. med. Sci. 221, 77.

Read, A. E., Sherlock, S., and Harrison, C. V. (1963). Gut, 4, 378.

Waldenström, J. (1950). Leber, Blutproteine und Nahrungseiweiss. Staffwechs Krh., Sonderband: XV. Tagung, p. 8, Bad Kissingen.

Willocx, R. G., and Isselbacher, K. J. (1961). Amer. J. Med., 30, 185. 